\title{
Transregional Security Cooperation after September 11, 2001
}

\author{
Dr. Dirk Nabers \\ Institute of Asian Affairs, Hamburg
}

\section{$\underline{\text { National Europe Centre Paper No. } 18}$}

Paper presented to conference on

The European Union in International Affairs, National Europe Centre, Australian National University, 3-4 July, 2002

Preliminary Draft. Do not quote without permission by the author! 


\section{Introduction}

Following Stephen Walt's definition, an alliance usually is a formal or informal commitment for security cooperation between two or more states. Although the particular arrangements of different alliances vary a lot, the defining feature of an alliance is a pledge for reciprocal military support against an external actor in some specified set of circumstances (Walt 1997). Its purpose, therefore, is to combine the two or more member states' military capabilities.

Taking into account this definition, it comes as no surprise that the United States' existing alliances' sustainability and potential were put to a test after the terrorist attacks of September $11^{\text {th }}, 2001$. In Europe, America's alliance partners showed immediate reaction by invoking Article 5 of the NATO treaty, thereby using its right of collective self-defense and promising to assist the United States in its war against terrorism "by taking forthwith, individually and in concert with the other Parties, such action as it deems necessary, including the use of armed force [...]" (Article 5 of the Washington Treaty). NATO's secretary-general Lord Robertson time and again reiterated that the United States of America can rely on the full support of its 18 NATO allies in the campaign against terrorism.

Turning to East Asia, what could Washington expect of its closest allies, Japan and South Korea? Definitely much less than from its European partners, and certainly no military role. Japan passed three laws in the six weeks after the terrorist attacks allowing the SDF to play a supporting role to the U.S. in its attacks on suspected terrorist bases, subsequently sending several ships of the Self-Defense Forces (SDF) into the Indian Ocean for humanitarian assistance and to provide logistic and other noncombatant support to the U.S. army. South Korea, host to 37,000 U.S. troops, has also voiced strong support for the United States since immediately after the September 11 suicide attacks. The Defense Ministry provided some non-combat soldiers to back the U.S.-led campaign and the government eventually approved a bill that would allow it to send a minimum number of military personnel necessary for anti-terrorism measures, ${ }_{\text {in }}$ December 2001, a medical and logistics unit of the South Korean forces was sent to Kyrgyzstan, northeast of Afghanistan.

Not surprisingly, some kind of transregional security cooperation developed over the Atlantic as well as over the Pacific after the terrorist attacks of September 11. Once again, only Asia-Europe security cooperation was conspicuous by absence as a link in the global alliance against terrorism. There seems to be almost no cooperation between Europe and Asia in the military realm, although the campaign against terrorism seemed to be a good opportunity to broaden global security cooperation.

The main question to be answered in the following analysis is what kind of global security architecture is emerging after September 11 and what roles Europe, East Asia and the United States could possibly assume in this structure. What are the prospects for a sustainable, triangular security partnership between East Asia, Europe

Australia and New Zealand have also given unequivocal support for the United States, offering elite Special Air Service troops for the US' response to terrorism. For the first time since its inauguration in 
and the United States? - The question refers to the old puzzle of IR theory, i.e. why states engage in security cooperation in the first place. The puzzle is solved differently by diverse theories:

- In its formulation by Kenneth Waltz (1979) or the successive interpretations by Joseph Grieco (Grieco 1990) and Mearsheimer (1994), realism is rather pessimistic about the prospects for cooperation. Traditional alliance theory assumes that states ally to balance against the superior power capabilities of other states (Waltz 1979). The imperative of survival presupposes that there are only two reasons why states cooperate with each other: balancing, which refers to an alliance against a prevailing threat, and bandwagoning, which is defined as an alignment of state with the source of danger (ibid, cf. also Wolfers 1962). This is the reason why the only type of security cooperation that really plays a major role in realist accounts is the alliance. All of Waltz's realist predecessors and theoretical companions fall within the broad compass of balance of power arguments. Examples are George Liska, who suggests that "alliances are against, and only derivatively for, someone or something" (Liska 1962: 12) and Hans J. Morgenthau, who depicts alliances as "a necessary function of the balance of power operating in a multiple state system" (Morgenthau 1967: 175). Modifying this traditional view, Walt was the first prominent scholar who supposed that power alone cannot explain balancing behaviour of states. Instead he proposes balance of threat theory as a better alternative than balance of power theory, suggesting that the level of threat is affected by geographic proximity, offensive capabilities, and perceived intentions of adversary states (Walt 1987: 5).

- It is hard to explain the various tendencies of security cooperation going on in international relations in terms of balancing of power concepts. As we can see from Walt's example, even realist authors tend to borrow elements such as trust, perceptions or the binding force of norms from other theories. The finding also applies to Randall Schweller's "motivational realism" (1996) and Robert Jervis' dictum that institutions have the capability to change preferences over outcomes (1999: 58-62). In neorealist accounts, especially, states' preferences are fixed by the survival imperative in anarchy. Surprisingly, for a long time the most serious challenge to realist balance of power theorizing came from a theory that is firmly rooted in the rationalist paradigm as well. Neoliberal institutionalist arguments (Keohane 1984; Keohane/Nye 2001; Oye 1986) also start from the assumption of self-interested actors operating in an anarchic state system. Yet, the dogmatic neorealist assumptions are somehow relaxed in neoinstitutionalist accounts. They easily soften the relative gains hypothesis in admitting the desire of states to achieve absolute gains in welfare and security. While realism cannot explain their existence except in the case of balancing, neoinstitutionalims provides factors such as lowered transaction costs, provision of information and institutionalized enforcement to account for their establishment. The bigger a coalition is, the more fruitful it might be for an external power to join it. In this sense, the provision of economic or military assistance can create effective allies, because it communicates favourable intentions. The hypothesis could then be: the more aid, the tighter the alliance. We can see such a development in Central Asia since the start of the United States' campaign against terrorism in autumn 2001. Furthermore, the effect of aid on political choices will be 
enhanced when a continuous supply of the goods in question is needed. Examples include food, money, and especially military equipment during wartime. In that sense, foreign aid can have an important effect on existing or newly developing loyalties by providing a clear and credible signal that a powerful state or alliance does not have belligerent intentions.

- While realism is a systemic theory and neoinstitutionalism has only recently tried to overcome the domestic/international divide by constructing two-level games (Putnam 1988; Evans et al. 1993; Zangl 1994; Nabers 2000), liberal accounts of security institution building look at domestic structures and processes to account for foreign policy changes of states (Czempiel 1981; Moravcsik 1997). Liberal theory considers alliance formation as the result of a convergence of benevolent, cooperation-prone national interests, encouraged by domestic coalitions for which such cooperation obtains priority (e.g. RisseKappen 1991). A noteworthy branch of liberal approaches is the theory of "democratic peace", originally developed by Immanuel Kant, but now an integral part of IR theorizing (esp. Doyle 1997). The main argument holds that democracies prefer peace to war because of citizens basic preservation instinct and their unwillingness to maintain costly military armies (Russett 1990, 1993). Consequently, democracies would choose to seek non-violent solutions to international conflicts, even with non-democratic regimes. Cooperative efforts to come to collaborate with rivalries and enemies are in this sense the result of the internal structure of a state (Müller 2002: 377). With respect to alliances, democracies have certainly better prospects for developing long-lasting, friendly relationships (Risse-Kappen 1995; Starr 1997). NATO and the Japanese-American alliance are the best examples for this argument. And it is indeed reasonable that the transfer of the structural and normative principles that guide conflict management inside democracies to the international level are the main causes for both the durability and rather smooth operation of alliances such as NATO.

- One important question is though left unanswered by liberal theorists. Why is there such a high variation in security policy behaviour of democratic states? Why do some states strive for integration of their respective foreign policies while others adopt a unilateral stance? It is difficult to answer these questions by looking at the structure of domestic systems alone; a possible explanation lies in customs or cultural habits, but these factors lie outside the realm of traditional liberal theories. They intrude into social constructivism. The analytical power of constructivist assumptions seems to be so strong that many supposedly realist or neoinstitutionalist accounts adopt categories that go far beyond the scope originally outlined by authors such as Walt and Keohane. Walt's theory lies outside the realm of traditional realist accounts in that it refers to perceptions and ideas in explaining alliance formation. The same is true for probably the most elaborate and elegant body of security cooperation theory, Alliance politics by Glenn Snyder $(1984,1997)$. Snyder, though writing in realist terms most of the time, finds it necessary to introduce concepts such as norms, thereby softening his realist assumptions and contradicting the rationalist paradigm that dominated IR theory for the last decades. Yet, his approach stops where social constructivism starts; while focusing on perceptions of states, he neglects the interactive moment that is inherent in any social relationship. Contrary, constructivists-according to their focus on processes-rely on concepts such as culture and identity. While culture refers to socially shared knowledge or 'intersubjective understandings' that can take 
the forms of norms, rules, institutions and so on, identity can have a strong intersubjective quality, too, since it is always constituted by two kinds of ideas: those held by the Self and those held by the Other (Wendt 1999: 224; Katzenstein 1996: 2). Positive representations of the Other usually emerge from mutual respect and cooperation. In international relations, this means that a state's identity will often depend on notions of a group of states of which it is a member. In our case, it is representations regions, the question of how deeply culture is internalized within the cooperative context, that will help us explain the state of transregional security cooperation after September 11. In this regard, coalition with other states may also be viewed as a way of defending one's own political principles. If statesmen believe their own system of government is inherently good, then cooperating with states with comparable systems must be considered good as well.

Let us look at the empirical findings now. I am interested in identifying the forces that led to the formation of transregional alliances in the war against terrorism by taking into consideration the various theoretical presuppositions that I introduced here. The question why transregional security cooperation takes place can only be answered deductively. The following analysis will thus contrast cooperation theory with recent developments in transregional security cooperation.

\section{Transregional Security Cooperation after September 11}

\subsection{The strengthening link: Transpacific Security Cooperation}

Assuming that of all the causes of the dissolution of an alliance, the most palpable one is an alteration in the nature of the threat that produced the original institution, and recognizing further the fact that the Soviet threat had disappeared by the end of the 1980s, it is extremely surprising that the Japanese-American security relationship is still well in place. What is more, the alliance has even been called "one of the most important bilateral relationships in the world" by former U.S. ambassador to Japan Mike Mansfield (NW, 8 October 2001). Thus, we have to ask why the alliance seems to be firmly in place. To answer this question, one has to take a closer look at intra-alliance developments since the mid-1990s, covering the April 1996 Hashimoto-Clinton summit and the 'Japan-US Joint Declaration on Security', the 'New Guidelines for Japan-US Defence Cooperation' (Nichibei bôei kyôryoku no tame no shishin), and the defence-related legislation that was pushed through the Japanese Diet in May 1999 and October 2001. The guidelines, especially, underwrite what was perceived as a wider and deeper bilateral defence cooperation between Japan and the US (esp. Nabers 2000; also Mulgan 2000 and Murata 2000). The new guidelines were issued on September 24, 1997, 18 months after Japanese and American government officials had agreed on the need for updating the 1978 Defence Cooperation Guidelines. They outline a framework for:

- cooperation between the Japanese Self-Defence Forces (SDF) and the US army 'under normal circumstances', meaning collaboration in peacetime; 
- cooperation in response to a direct armed attack against Japan. While the SDF will primarily conduct defensive operations on the territory of Japan and its surrounding waters and airspace, US forces will offer support;

- cooperation 'in situations in areas surrounding Japan that will have an important influence on Japan's peace and security'. Functions and fields of bilateral cooperation include humanitarian relief activities, search and rescue measures, non-combatant evacuation operations, Japan's support for U.S. forces activities, and Japan-US operational cooperation (JT, 24.9.1997; DY, 24.9.1997).

In May 1999 three guidelines-related bills were passed in the two houses of the Japanese Diet, one allowing SDF rear area support (kôhô shien) for US military action, one amending the 1996 Acquisistion and Cross Servicing Agreement (ACSA, Buppin ekimu sôgô teikyô kyôtei) to permit the mutual provision of necessary goods and services in case of a military emergency 'in the areas surrounding Japan', and the last revising the SDF law (Jieitaihô) to allow the dispatch of ships and helicopters of the SDF to rescue Japanese overseas (JT, 20.2.1999; $D Y, 16.3 .1999,16.4 .1999)$.

This development represents the most significant expansion of Japan's responsibilities in the alliance since its foundation in the 1950s. While the engagement of the SDF in combatant roles remains restricted to self-defence and the Japanese government's neglect of the right to collective self-defence remains untouched, the new guidelines underwrite deeper and wider bilateral defence cooperation between Japan and the US (Mulgan 2000: 227-228). In other words, Japan is able to preserve its traditional identity of self restraint in military affairs, yet is able to demonstrate quite clearly its willingness to broaden its commitments to the US.

By doing this, it becomes clear that Japan is still unwilling to give full combat support to the U.S. in times of crises; Tokyo's prior goal is to preserve the US presence in East Asia, even amid widespread resentments within Japanese political circles: 'We don't know where this will take us', said Seiji Maehara, a legislator for the Democratic Party of Japan, the main opposition party. 'We consider the alliance very important. But we have to convey the Japanese people's anxiety about where we will be taken by the Americans.' (IHT, 7 February 2001). Even if we assume that identification with others is seldom total (Wendt 1999: 306), collective identity still implies a readiness when necessary to make sacrifices. As Okamoto Yukio contemplates, the Japanese-US relationship constitutes 'a security alliance that works fine in peace but which will fail the most likely tests of war' (Stokes and Shinn 1998: 1). The first such test came after the terrorist bombings of the WTC and Pentagon in the United States and the U.S. subsequent engagement in its war against terrorism.

After the widely perceived humiliation in the Gulf War ten years ago, when Japan refrained from supporting the United States in any meaningful military way due to constitutional restraints, the government in Tokyo has tried to incrementally change Japan's defense posture and engage more actively in international security affairs. However, the alliance between Japan and the U.S. seemed to remain unbalanced throughout the 1990s. It is the terrorist attacks on Washington and New York of September 2001 that threatened to expose anew Japan's shortcomings in dealing with international crises at Washington's side. 
So what could Washington expect of its closest ally in East Asia in its campaign against terrorism? Definitely much less than from its European partners, and certainly no military role. As we have seen, Article 9 of the Japanese constitution prohibits - on the interpretation of the Japanese government - the engagement of the SelfDefense Forces (SDF) in combatant roles; their task remains restricted to self-defense, and the Japanese government's neglect of the right to collective self-defense remained untouched over the years after the end of the Cold War. However, a debate within Japan about possible roles of the SDF in a military crisis in the areas surrounding Japan has once again started after September 11 (Nabers 2001).

This finally led to a broad engagement of Japanese forces in the Indian Ocean and in Afghanistan. To counter criticism and show the world that it is able to act quickly in situations of crises, Japan passed three laws in the six weeks after the terrorist attacks allowing the SDF to play a supporting role to the U.S. in its attacks on suspected terrorist bases. The bills allow the Japanese forces to provide logistic and other noncombatant support to the U.S. army, engage in search-and-rescue activities for military personnel and carry out humanitarian relief operations as well as guard U.S. bases in Japan or fire on suspicious vessels in territorial waters. To make swift decisions possible, the government was obliged to seek Diet approval only 20 days after the dispatch of the SDF (for a detailed analysis see McCormack 2001).

In November and December, the Japanese government eventually sent six ships of the Self-Defense Forces to the Indian Ocean to support the American activities; in February 2002, three new warships and about 700 soldiers replaced these vessels (AWSJ, 11 February 2002). Japan's contribution also covered refugee assistance as well as peace and reconstruction efforts in Afghanistan after the fighting was over (MOFA 2002). Although the Japanese ships were only providing noncombat backing for US troops, many experts call this development an irreversible change with a long-lasting effect (i.e. FEER, 1 November 2001). Considering the fact that there are ten thousands of American and British soldiers fighting the war against terrorism, uncountable naval vessels, air fighters and other equipment, the logistical efforts of keeping these in fighting conditions are tremendous. This makes the Japanese contribution even more significant. On the other hand, Japan's decision to refrain from direct engagement in fighting leaves the traditional interpretation of its pacifist constitution untouched. By reaching this solution Japan seems to have found the a "third way" between the unwarranted nationalism of the first half of the last century and the embellished pacifism of the latter half.

As regards the contribution of other major East Asian powers, China and South Korea were equally quick to support the U.S-led coalition, although neither was instantly willing to send troops into the Indian Ocean or to Afghanistan. Surprisingly, President Jiang Zemin of China was one of the first world leaders to offer condolences. Afterwards, Beijing decided to vote for anti-terrorism resolutions in the United Nations Security Council and put the campaign against terrorism on top of the agenda for the Shanghai APEC meeting in October. Furthermore, the Chinese government provided intelligence and information on global terrorism and extended food aid for refugees (for implications see Glosserman 2001).

South Korea was no exception when it came to the responsibility of joining the international coalition against terrorism. The Korean government drafted an anti-terrorism bill in February 2002 (KH, 10 February 2002), as 
the nation had no legal code exclusively addressing terrorism. In June 2002, the South Korean government eventually decided to send medics and military equipment to Afghanistan to help the central Asian country rebuild its armed forces. At the request of the United States, Seoul will also provide about 50.000 units of military material such as shovels, rucksacks and walkie-talkies (KT, 14 June 2002). Before, Seoul in December 2001 provided the first container of relief goods worth 1 million US\$ to the UN Children's Fund (UNICEF) as part of a total sum of 12 million US\$ in humanitarian aid for Afghan refugees to neighbouring countries, which had been decided in October by the Korean government (KH, 24 December 2001). Also in December, the United States asked Seoul to dispatch sea and air transport craft and personnel to assist its military campaign in Afghanistan. The plan was eventually approved by the National Assembly; at the end of December 500 troops for medical and logistical tasks were sent out; 100 medical and logistic troops have subsequently been stationed in Kyrgyzstan, northeast of Afghanistan. (KH, 7 December 2002). Finally, military officials from South Korea and the U.S. have also agreed in February 2002 to coordinate their combined forces for future emergency situations, saying that military helicopters will be ready to provide transportation in case of medical emergencies and search and rescue missions (KH, 1 March 2002).

All in all, the East Asian contribution to the campaign in Afghanistan has to be judged significant, although it was only in non-combat areas. Japan's decision to engage in rear-area support for the U.S. campaign against terrorism is unprecedented; South Korea was no exception when it came to joining the international coalition against terrorism, and China allied with the United States by voting for anti-terrorism resolutions in the United Nations Security Council. All this was unthinkable only a few years ago. While East Asia contributed more than could be expected, Europe, the U.S.' strongest military partner, was divided between engagement and hesitancy. I will to turn to the development of the transatlantic link in the next section.

\subsection{The weakening link: Transatlantic Security Cooperation}

Since alliances are not only aggregations of national power and purpose but are institutions as well, national governments not only influence the development of the institution, but the institution can exert influence on foreign policy behaviour as well. Institutions inherit explicit and persistent sets of principles, norms, rules and procedures that prescribe behavioral roles and constrain activity; thus, they offer the structural framework "around which actors' expectations converge in a given area of international relations" (Krasner 1983: 1).

On the basis of this theoretical assumption, one can presume that, firstly, an institution's structural adjustment will also influence its member countries' policy towards the institution, and secondly, the institution is likely to adapt to changes in its international environment. In the decade following the end of the Cold War, at least three mutually contingent developments occurred, which are of particular relevance for the development of the EU's security posture: 1) a shift of perceived risks from Europe to other world regions such as Northeast Asia, the Middle East, and Central Asia, 2) the development of a genuine European defense pillar, and 3) a broadening of NATO's duties, both geographically and functionally. These developments were reinforced by the terrorist attacks of September 11, 2001, on New York and Washington, and the subsequent War against global terrorism. 
Analysing developments in the field of global security policy after September 11, a cliché has become popular: the United States is the power that fights the wars, the United Nations feeds, the European Union and Japan finances, while European and East Asian soldiers keep the peace in their respective regions (cf. for example NYT, 16 March 2002). Much seems to be true about this formula. With regards to NATO, European policy makers realize that they are more and more becoming secondary to the U.S., unable to influence their alliance partner's foreign policy goals because they can bring in too few military assets into NATO. This development has serious implications for the future of NATO. The transatlantic security cooperation has ceased to be the oldstyle alliance type, balancing against the threat of the Warsaw pact; new threats are on the agenda-biological and chemical substances in the mail, chemical weapons in a subway ventilation system, or nuclear proliferation to the hands of individuals-leading to an irrevocable transformation of the alliance with great impact on its member countries security policies. Already before September 11, 2001, the U.S. government has repeatedly made very clear it expects a broadening of NATO's functions in the future. In a speech delivered in Berlin on 13 May 1998, the $50^{\text {th }}$ anniversary of the lifting of the Berlin blockade, President Clinton listed up the priorities of U.S. policy towards Europe:

Yesterday's NATO guarded our borders against direct military invasion. Tomorrow's Alliance must continue to defend enlarged borders and defend against threats to our security from beyond them-the spread of weapons of mass destruction, ethnic violence, regional conflict [...] We begin with our common security of which NATO is the bedrock. [...] we must do more to promote prosperity throughout our community. [...] America will continue to support Europe's march toward integration. (United States Information Agency 1998a)

This concept obviously implies a broadening, if not globalization of NATO's duties. It indicates an attempt of the United States to transform the Alliance into an instrument of power projection. The concept was further specified by the U.S. government in the months to come and it was properly reflected in the Alliance's Strategic Concept, as approved by the Washington summit meeting of 23-24 April 1999, celebrating NATO's 50 ${ }^{\text {th }}$ birthday. According to the document, the security of the Alliance is subject to

a wide variety of military and non-military risks which are multi-directional and often difficult to predict. These risks include uncertainty and instability in and around the Euro-Atlantic area and the possibility of regional crises at the periphery of the Alliance, which could evolve rapidly. [...] Ethnic and religious rivalries, territorial disputes, inadequate or failed efforts at reform, the abuse of human rights, and the dissolution of states can lead to local and even regional instability. (NATO 1999a)

The new U.S. understanding of its strategic doctrine-defense of common interests, reaching beyond collective defense of members' territories, was not backed by all NATO allies. As before, the U.S.' European allies are principally interested in having the U.S. Army at their front door-provided the transatlantic relationship rests on partnership, not on dominance. 
This became more apparent after the first phase of the fight against terrorism-the removal of the Taliban from power in Afghanistan-was over (for implications see Hamilton 2002: 8). French Foreign Minister Hubert Vedrine said that Europe "is threatened by a new simplistic approach that reduces all the problems in the world to the struggle against terrorism", and when President Bush came up with his notion of an "axis of evil", German Defense Minister Rudolf Scharping said he favoured a political strategy for dealing with Iraq rather than a military one. American Secretary of State Colin Powell reiterated that Europe still plays an important role in the United States strategic considerations, but on the other hand indicated that Washington would not sacrifice its interests in the pursuit of multilateralism (IHT, 7 February 2002). In other words: The USA is willing to act unilaterally in case the alliance partners do not agree (NYT, 23 February 2002).

However, it is not clear whether the alliance partners will always agree when it comes to actual fighting. The real issues came to the table with the terrorist attacks on New York and Washington: a growing disparity in military capabilities and its impact on collective action, and, as important, an obvious dichotomy in views of how to deal with future security problems. Although America's alliance partners in Europe showed immediate reaction by invoking Article 5 of the NATO treaty, Washington more or less prosecuted the war on its own terms. NATO's secretary-general Lord Robertson time and again reiterated that the United States of America can rely on the full support of its 18 NATO allies in the campaign against terrorism. However, while American President Bush wants to increase the Pentagon's defense budget by 120 billion US\$ until 2007-including an increase of 48 billion US\$ for 2003-Europe spends only 140 billion US\$ per year (FAZ, 1 February 2002; NYT, 16 March 2002). That leads to an ever widening capability gap between Europe and the United States: "The United States is simply pulling away from its own allies". (Hamilton 2002: 9) Eventually, Great Britain was once again the only ally that contributed substantially to the military mission of the United States. As Paul Dibb concludes, Prime Minister Tony "Blair's help has been crucial in shoring up support not only among Europeans but also with Middle Eastern countries, Pakistan and Russia." (Dibb 2002: 139)

A new NATO will definitely focus less on Europe and more on the wider world. Europe will help to an extent that is possible militarily and politically. To provide this support might be one of Europe's tasks as an alliance partner. But keeping peace in Europe alone is a complex mission, which could be fulfilled only with the help of the U.S. in the past. American security interests are shifting away from Europe, while the Europeans themselves claim a European responsibility for a new European security architecture.

\subsection{The missing link: Asia-Europe Security Cooperation}

While both Asia and North America as well as the USA and the European Union cooperated in the Afghanistan War, there was almost no visible cooperative effort between Asia and Europe. This finding comes as no surprise since there exists no formal military alliance between Asia and Europe. The only institution that could in the long run also deal with security problems would be the Asia-Europe Meeting (ASEM), but since its inaugural meeting in Bangkok in March 1996, little has actually been achieved in this field (for an overview see Sukontasap/Santipitaks 2000). 
Whether ASEM can play a role in the security field mainly depends on two aspects: the readiness of its members to see the institution take on an active political role, and the frequency with which it is utilised for such a purpose. The example of the Asia-Pacific Economic Cooperation (APEC) shows how a forum that was originally designed to handle trade problems can take a step towards discussing security problems as well. At APEC's annual summit in October 2001 in Shanghai, the political leaders of its member countries issued a joint declaration pledging strengthened global cooperation in fighting transnational terrorism (JT, 24 October 2001; $J T, 26$ October 2001). In that sense, APEC might be a significant stabilizer for political ties among the major powers in the Asia-Pacific, China, Japan, Russia and the United States. However, as in almost all APEC meetings since the forum's inauguration in 1989, there was little in the final declaration beyond catchphrase; no specific actions were endorsed.

While the Asia-Pacific region nonetheless has several functioning alliances plus a forum for consultation and discussing Confidence and Security-Building Measures, the ASEAN Regional Forum (ARF), Europe-Asia relations lack substance in every respect. Although the forum envisaged "a new comprehensive Asia-Europe partnership for growth", aimed at "contributing to peace, global stability and prosperity" (Chairman's Statement 1996), the forum did not develop beyond the stage of the usual platitudes and pledges to work together. On the first three summit meetings in Bangkok 1996, London 1998 and Seoul 2000, the leaders reaffirmed their commitment to pursuing a secure international environment (see various Chairman's Staements). The significance of developments on the Korean peninsula, stability in East Timor and Southeastern Europe were also emphasized. It remains to be seen if Copenhagen will generate a declaration that accentuates the importance of combating global terrorism and ASEM's support for the United States.

Several calls for closer cooperation between Asia and Europe have actually been issued after the dramatic events of September 11. Delegates from the 25 member countries of ASEM reached a consensus on international cooperation to combat transnational crimes soon after the attacks on New York and Washington when they gathered in Beijing on September 19. According to the final report, which was co-chaired by Italian minister of the Interior Claudio Scajola and Chinese Minister of Public Security Jia Chunwang, participants agreed to "enhance information exchanges, increase mutual trust and establish bilateral and multilateral cooperation mechanisms for fighting transnational crimes." (XNA, 19 September 2001). To facilitate cooperation between Asia and Europe, it was agreed that China and Italy would set up liaison offices in Rome and Beijing. Jia pointed out that emphasis of the cooperative efforts should be put on strengthening ASEM law enforcement cooperation, which he said is of vital importance to the prevention and suppression of transnational crimes. In this context, the European delegates learned that China has taken an active role in Interpol and the United Nations law enforcement multilateral cooperation in recent years and has signed bilateral and multilateral treaties on law enforcement cooperation with some other countries (XNA, 17 September 2001). Jia finally proposed to take the Beijing seminar as a beginning to gradually form up a long-term mechanism for ASEM cooperation in law enforcement (Zhongguo Xinwen She News Agency, 19 September 2001). 
With regards to the new security situation after September 2001, Guy Legras, director general for external relations of the European Commission, said in November 2001 it is vital for the two sides to "assess" the Afghan situation and "define priorities" in dealing with it. Yet again Legras refrained from identifying specific common views held by EU and Asian countries; instead he sticked to the reiteration of the need to "act in a very coordinated manner", claiming that a "common sense" dictates the necessity of securing "minimum order" and some form of authority to resolve the Afghanistan conflict (Kyodo, 22 November 2001).

While Legras speaks for the EU, there have also been several bilateral declarations of intent. To quote some examples of Japanese diplomacy, Prime Minister Jun'ichirô Koizumi and Romanian President Ion Iliescu in February 2002 reaffirmed their resolve to cooperate in countering terrorism, agreeing that acts of terror "can never be justified for whatever reason" (XNA, 15 February 2002). A couple of days later, Japanese Defense Agency chief Gen Nakatani agreed with French Defense Minister Alain Richard to promote defense exchanges between the two countries as well as exchanges in the field of information technology. Among others, the two politicians stressed the need to discuss modernizing their respective military forces to respond to biological and chemical weapons (Kyodo, 20 February 2002; XNA, 21 February 2002).

In the aftermath of September 11 the Japanese government made it very clear though that Japan's diplomacy is centered on its relationship with the United States (JT, 9 December 2001). In December, another declaration was issued when Japan and the EU agreed on a plan of action to strengthen bilateral ties. The action plan designates a new decade of EU-Japan cooperation, asserting - among others, that global peace and security must be enhanced (AS online, 11 December 2001; NZZ, 10.12.2001). Specific areas of cooperation were once again not stipulated, but the following course of action was considered:

- $\quad$ strengthening policy dialogue and coordination in Afghanistan and neighbouring countries,

- active cooperation in providing humanitarian assistance to refugees and displaced persons,

- $\quad$ assistance for the reconstruction of postwar Afghanistan as well as development assistance to Pakistan and other countries neighbouring Afghanistan (Text of declaration in Kyodo, 8 December 2001).

Again, these words do not surpass the point of mere exhortation. Security cooperation between Asia and Europe is still in a prenatal phase. To explain this situation, it might be argued that there still exists a lack of knowledge about each other. "But it is not enough to have knowledge", said Tommy Koh, Singapore's ambassador at large, "you need mutual respect too. Most Europeans still do not regard Asians as their equals." (cit. in NW, 25 May 2001). Citing as an example the ASEAN-European Union summit in Vientiane, Laos, in December 2000, where only three of the 15 European states sent ministers to the first such meeting in three years, he complained about the difficulty of attracting the Europeans attention. It therefore comes as no surprise that Europe takes a backseat in this triangular relationship.

The fears of receding European interest and 'ASEM fatigue' came to the fore again in June 2002 at the fourth meeting of foreign ministers from the two continents. Only four of the 15 European Union countries were represented by full ministers; and out of the 10 Asian members of the forum, three sent lower-level officials. 
Again, the delegates promised to take joint action in the fight against terrorism, as well as in controlling illegal migration. The only significant news of the gathering was that ASEM managed to come up with declarations on the Middle East and on the India-Pakistan confrontation (ST, 11 June 2002). Agreement seemed to be a tough delivery though, considering the fact that some of the Asian countries have Muslim populations.

Regrettably, many possible areas of cooperation between Europe and Asia have not been explored by the two sides. One such area is cooperation in development assistance in war-torn countries like Afghanistan. For example, Germany and Japan are the biggest donors to Central Asia. Hence, their role must not necessarily be military. By hosting the two central conferences on the future of Afghanistan in Bonn in December 2001 and in Tokyo in January 2002, both countries have provided very important resources for rebuilding the country. Afghanistan is going to be a long-term process. Dealing with the plight of refugees, removing mines and ensuring democracy is the work that is still to be done. The question for the Asian-European security link might be how much initiative and leadership the two sides can provide in these nonmilitary efforts in the future.

\section{Conclusion}

Explaining global security cooperation after September 11, three different developments are apparent: it comes as no surprise that transpacific collaboration is strengthening; there have already been such signs since the mid1990s, especially in the Japanese-American relationship. More surprising might be the revelation that the transatlantic alliance is in its first real crisis after more than fifty years. This certainly has something to do with a shift of perceived risks from Europe to other world regions such as Northeast Asia, the Middle East, and Central Asia. If we describe the European-American security relationship on the basis of the theoretical assumptions of the introductory part of this article, the most obvious finding would be that the new security situation after the breakdown of the Berlin Wall has not triggered new balance of power behaviour in the shape of rivalling alliances among the powers of Europe, as predicted by neorealists. NATO is slowly transforming from a collective-self defense pact, whose primary task was balancing the Soviet Union, to a mechanism of cooperative security. From the perspective of the Europeans, NATO is still the most important guarantor of peace on the continent, but the means have changed: adding new members to the alliance and achieving the closest possible working relationship with Russia is high on the agenda. The inherent dilemma is obvious: An alliance that has transformed into a political organization is of little military interest to the Americans; on the other hand, were NATO to become an organization engaged first and foremost in the fight against world wide terrorism, the Europeans would soon fatigue both militarily and politically.

When it comes to the question why NATO does not dissolve, neoinstitutionalists offer intriguing arguments. According to this theory, security and welfare are always functions of the investment costs for cooperation. In this respect, alliances such as NATO or the alliances of the USA with Japan and Korea are able to reduce transaction costs among parties by opening up communication channels and providing relevant information. Certainly, as Wallander (2000) has correctly pointed out, NATO's new structure has evolved from its assets developed during the Cold War, that is, assets for political discussion and decision making, for military planning, 
organization and implementation. Neoinstitutionalists suggest that these assets persist because they are costly to create and less costly to maintain. In the NATO case as well as in the Japanese-American and Korean-American alliances, we see strong evidence for this argument.

What has become obvious in the war against terrorism is that an essential component of the American strategy is the creation of "a coalition of coalitions". Although this coalition needs not be as formal as NATO or the USJapanese alliance, and although members of various coalitions contribute to the military efforts in varying degrees, one essential link in the global security triangle is missing, that is, Asia-Europe security cooperation. It seems as if active security alliance formation is based primarily on bilateral or multilateral relations with the United States. As Brad Glosserman succinctly put it: "Relations with the United States are the grand prize as governments scramble for position in the war against terrorism." (Glosserman 2001: 1).

ASEM could provide a new mechanism for the member countries to promote understanding and resolve contradictions through negotiations. Already in the past, the grouping has spawned many cooperation projects on the so called non-governmental track-two level, meaning interaction between think tanks, journalists, scholars, and even the private sector. Yet, on the political level, it has not managed to escape from the stage of being a talk shop.

Constructivism—by offering concepts like culture, norms and identity—might be well equipped to explain this development. Since the understandings of how the European security community should look like perceptibly diverge in Europe and the United States, we can expect the European Union to become more autonomous in the future. The mechanism is underscored by a strengthened European identity as a political community, consciously segregating itself from the American hegemony. Correspondingly, the weakening of NATO might continue. On the other hand, while the high density of social-communicative processes between East Asia and the United States affect and shape the identities and interests of the states in the region to a rising extent and certain qualitative new features of solidarity seem to emerge, the level of communication between East Asia and Europe is still low. Certain interest-shaping norms, such as the protection of human rights, are still hampering deeper cooperation. While Washington has already decided to go it alone if necessary, Europe and Asia will have to decide whether they want to be regional or a global powers. For the foreseeable future, both will—due to operational deficits and legal considerations-be more or less restricted on a regional role, assuming occasional peacekeeping roles in other regions.

In conclusion, one can say that threat perceptions and certain role-specific identities are probably responsible for what is going on in transregional security cooperation after September 11. The intensity of cooperation may depend on the membership of a country in what Buzan et al. once called a 'security complex', which "is actually a constellation of security concerns" (Buzan, Waever and de Wilde 1998: 43). The transfer of the structural and normative principles that guide conflict management inside democracies to the international level—as predicted by liberals-is not convincing in this context, since Pakistan and some other non-democratic countries have also joined the anti-terror alliance. In the future, much will depend on how states and regions perceive themselves in 
the global security architecture. This, in turn, will determine the decision for or against co-operation, not so much the material capabilities of states.

\section{Bibliography}

AS online, 12 December 2001, "Japan, EU agree on plan of action"

Asia-Europe Meeting, ASEM (1996) Chairman's Statement of the Asia-Europe-Meeting, Bangkok, 2 March 1996, http://europa.eu.int [13 January 2002].

Asia-Europe Meeting, ASEM (1998) Chairman's Statement of the Second Asia-Europe-Meeting, London, 3-4 April 1998, http://europa.eu.int [13 January 2002].

Asia-Europe Meeting, ASEM (2000) Chairman's Statement of the Third Asia-Europe-Meeting, Seoul, 20-21 October 2000, http://europa.eu.int [13 January 2002].

AWSJ (Asian Wall Street Journal), 11 February 2002, "Tokyo Will Deploy Additional Troops To Aid Terror War"

Czempiel, Ernst-Otto (1981) Internationale Beziehungen. Ein Konfliktmodell (München: UTB).

Dibb, Paul (2002) "The Future of International Coalitions: How Useful? How Manageable?", The Washington Quarterly 25,2, pp. 131-144.

Doyle, Michael W. (1997) Ways of War and Peace. Realism. Liberalism, and Socialism (New York and London: W.W. Norton).

Glosserman, Brad (2001) "The New Trilateral Strategic Calculus", PacNet Newsletter 51, 21 December 2001, http://www.csis.org [25 March 2002].

Grieco, Joseph M. (1990) Cooperation among Nations. Europe, America, and Non-Tariff Barriers to Trade (Ithaca, NY: Cornell University Press).

Hamilton, Daniel S. (2002) German-American Relations and the Campaign Against Terrorism. American Institute for Contemporary German Studies, The Johns Hopkins University. Washington D.C.

IHT (International Herald Tribune), 7 February 2002, Suzanne Daley "France Upbraids U.S. as 'Simplistic'" 
Jervis, Robert (1999) "Realism, Neoliberalism, and Cooperation: Understanding the Debate", International Security 24,1, pp. 42-63.

JT (The Japan Times), 24 October 2001, "APEC resumes its march"

JT (The Japan Times), 26 October 2001, "Terrorism pact proves APEC is not simply a costly party"

JT (The Japan Times), 9 December 2001, "Japan's role in rebuilding Afghanistan"

Katzenstein, Peter J. (ed.) (1996) The Culture of National Security: Norms and Identity in World Politics (New York: Columbia University Press).

Keohane, Robert O. (1984) After Hegemony: Cooperation and Discord in the World Political Economy (Pinceton, NJ: Princeton University Press).

Keohane, Robert O./Nye, Joseph S. (2001) Power and Interdependence (New York: Longman).

KH (The Korea Herald), 7 December 2001, "U.S. requests South Korea transport units for anti-terrorism war in Afghanistan"

KH (The Korea Herald), 24 December 2001, "KOICA to send \$1 mil. relief aid to Afghan refugees soon"

KH (The Korea Herald), 10 February 2002, "South Korea's anti-terrorism bill under attack by civil libertarians"

KH (The Korea Herald), 1 March 2002, "US Anti-terror Unit to be Deployed in Korea"

KT (The Korea Times), 14 June 2002, "Korea to Send Troops to Afghanistan"

Kyodo (engl.), 22 November 2001 (BBC-Email, 23 November 2001), "EU official in Tokyo calls for closer cooperation on Afghanistan"

Kyodo (engl.), 8 December 2001 (BBC-Email, 9 December 2001), "Japan, Europe adopt joint declaration on terrorism"

Kyodo (engl.), 20 February 2002 (BBC-Email, 21 February 2002), "Japan, France defence chiefs agree to strengthen ties"

McCormack, Gavan (2001) "Japan's Afghan Expedition", 5 November 2001, http://www.iwanami.co.jp [18 March 2002]. 
MOFA, Ministry of Foreign Affairs, Japan (2002) "Campaign Against Terrorism", http://www.mofa.go.jp [3 April 2002].

Moravcsik, Andrew (1997) "Taking Preferences Seriously: A Liberal Theory of International Politics", International Organization 51,4, pp. 513-553.

Morgenthau, Hans J. (1967) Politics among Nations (4th ed., New York: Knopf).

Müller, Harald (2002) "Security Cooperation", Carlsnaes, Walter/Risse, Thomas/Simmons, Beth A. (ed.) Handbook of International Relations (London: Sage), pp. 369-391.

Mulgan, Aurelia George (2000) 'Beyond Self-defence? Evaluating Japan's Regional Security Role under the New Defenc Cooperation Guidelines', Pacifica Review 12,3 (October), pp. 223-246.

Nabers, Dirk (2001) 'Japan's reaction to the terrorist attacks on its closest ally', NIASNytt, Nordic Newsletter of Asian Studies 4/01, http://130.225.203.37/Nytt/stories/storyReader\$102 [8 January 2002].

NW (The Nikkei Weekly), 25 May 2001, "Asia-Europe forum hits all the wrong notes"

NW (The Nikkei Weekly), 8 October 2001, "Former U.S. ambassador to Japan dies aged 98"

NYT (The New York Times), 23 February 2002, Steven Erlanger "Europe Seethes as the U.S. Flies Solo in World Affairs"

Risse-Kappen, Thomas (1991) "Did 'Peace Through Strength' End the Cold War? Lessons from INF", International Security 16,1, pp. 162-188.

Risse-Kappen, Thomas (1995) Cooperation Among Democracies. The European Influence on US Foreign Policy (Princeton: Princeton University Press).

Russett, Bruce (1990) Controlling the Sword (Cambridge: Harvard University Press).

Russett, Bruce (1993) Grasping the Democratic Peace. Pronciples for a Post-Cold War World (Princeton: Princeton University Press).

Schweller, Randall (1996) "Neorealism's Status-Quo Bias: What Security Dilemma?", Security Studies 5,3, pp. 90-121.

Snyder, Glenn H. (1984) "The Security Dilemma in Alliance Politics", World Politics 36,4, pp. 461-495. 
Snyder, Glenn H. (1997) Alliance Politics (Ithaca: Cornell University Press).

ST (The Straits Times), 11 June 2002, "Asem fatigue: Was Madrid a symptom or cure?"

Starr, Harvey (1997) "Democracy and Integration. Why Democracies Don't Fight Each Other", Journal of Peace Research 34,2, pp. 153-162.

Stokes, Bruce/Shinn, James (1998) The Tests of war and the Strains of Peace: The U.S.-Japan Security Relationship (New York: Council on Foreign Relations)

Sukontasap, Darmp/Santipitaks, Busadee (2000) "ASEM: A Political and Security Agenda", Japan Center for International Exchange (JCIE), ed., Strengthening International Order. The Role of Asia-Europe Co-operation. A CAEC Task Force Report (Tokyo: JCIE), pp. 98-107.

United States Information Agency (1998) "Remarks by the President to the people of Germany, Berlin, 13 May 1998" Public Diplomacy Query (PDQ), http://pdq2.usia.gov [25 June 2000].

Walt, Stephen M. (1987) The Origins of Alliances (Ithaca and London: Cornell University Press)

Walt, Stephen M. (1997) 'Why Alliances Endure or Collapse', Survival 39,1, pp. 156-176.

Waltz, Kenneth N. (1979) Theory of International Politics (New York: Random House).

Waltz, Kenneth N. (1993) "The Emerging Structure of International Politics", International Security 18,2, pp. 44-79.

Wendt, Alexander (1999) Social Theory of International Politics (Cambridge: Cambridge University Press).

XNA, 19 September 2001, "China's security minister on fighting international terrorism"

XNA, 19 September 2001, "China: Asia-Europe Meeting discusses terrorism, transnational crime"

XNA, 15 February 2002, "Japan, Romania Agree on Anti-terrorism Cooperation"

XNA, 21 February 2002, "Japan, France Agree to Promote Defense Exchanges"

Zhongguo Xinwen She news agency, 19 September 2001 (BBC-Email, 19 September 2001), "China: AsiaEurope Meeting agrees on joint fight against transnational crime" 